\title{
J051012
}

\section{妔空エンジン用低圧タービンの高負荷・高効率化に関する研究 (後縟形状の効果)}

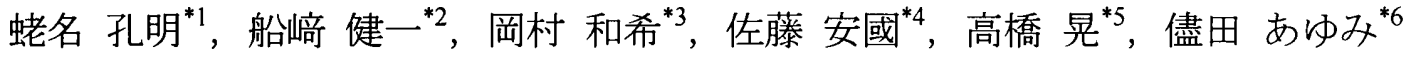 \\ Studies on High-Lift and High-Efficiency LP Turbine \\ (Effect of Trailing Edge Shape)
}

\author{
Yoshiaki EBINA ${ }^{* 1}$ and Ken-ichi FUNAZAKI and Kazuki OKAMURA and Yasukuni SATO and \\ Akira TAKAHASHI and Ayumi MAMADA \\ ${ }^{* 1}$ Graduate School of Iwate Univ. Dept. of Mechanical Engineering \\ Ueda 4-3-5, Morioka, Iwate, 020-8551 Japan
}

In order to improve the efficiency of high-lift low pressure turbines, this paper looks into the trailing edge shape. Turbine blade loss was investigated experimentally in a linear cascade wind tunnel by comparing the reference blade with a semicircular trailing edge and a blade with a tapered trailing edge. The pressure loss was measured by miniature Pitot tubes in order to understand the flow field around the blade. Hot-wire probe measurement was conducted in the region extending from the vicinity of the suction surface to the blade downstream. The Reynolds number based on the chord length was varied in the range of 40,000 to 170,000 to simulate a typical flight condition. Furthermore, upstream stator wakes were emulated by a wake generator consisting of cylindrical bars mounted on a motor-driven belt upstream of the cascade. The new blade model was found to achieve higher efficiency compared to the reference model under the operating conditions reproduced in the experiment.

Key Words : Turbine, Unsteady Flow, Separation, Boundary Layer, Wake

\section{1. 粕}

現在，航空機用エンジンには，低燃費，低騒音などの高い環境適合性を有することから，ターボファンエンジ ンが広く採用されている．しかしながら，近年の原油価格の高騰や環境負荷への考慮，エアライン業界の競争激 化などの観点から，ターボファンエンジンには更なる性能向上が望まれている.

ターボファンエンジンはエンジン前部にある巨大なファンによって推力の大半を生み出している. エンジン内 においてファンが生み出寸推力の割合は，近年のトレンドである高バイパス比化に伴い更に増加傾向にある．本 研究対象の低圧タービンはファンの駆動を担っているため, 低圧タービンの高効率化がターボファンエンジンの 性能向上への大きな鍵となっている.

一方で，実機環境下における低圧タービン翼周りは，複雑な流れ場となっている．たとえば，航空機は地表付 近から高度 $10,000 \mathrm{~m}$ 以上の高高度までの幅広い空間を飛行するが, その閒エンジンの運転条件も大きく変化する. 特に, 飛行時間の大半を占める高高度巡航時には, 周囲空気密度の低下によってエンジン内部は低レイノルズ数 条件となる．このような低レイノルズ数条件下においては，低圧タービン翼負圧面上に発生する境界層は層流境 界層の占める割合が多くなり，剥離が生じやすくなる．剥離の発生はタービン効率の著しい低下を引き起こす要

"1 学生員, 岩手大学 大学院（T020-8551 岩手県盛岡市上田 4-3-5)

2 正員, 岩手大学 工学部

3 株式会社 IHI

*4 非会員, 岩手大学, 大学院

5 株式会社 IHI

"6 株式会社 IHI

E-mail: 2412004@iwate-u.ac.jp

[No.12-1］日本機械学会 2012 年度年次大会講演論文集 [2012.9.9-12, 金沢] 
因となる. また，実機環境下で上流翼列から生ずる wake の流入はタービン翼周りの流れ場に影響を与える. wake 通過条件下では, wake が翼負圧面上で生ずる剥離と干渉し, 時間平均的に剥離が抑制される効果がある事が知ら れている. (1)

このように複雑な流れ場となっている低圧タービンの高効率化について, 本研究ではタービン翼後縁形状に着 目して調查を実施した. 実験では直線翼列試験装置を使用し, 航空機用低圧タービン翼と, その後縁厚みを削減 したモデルに関して計测を行った．更に，レイノルズ数の変化と上流静翼列からの wake の流入を模擬した実環 境に近い条件下での計測も実施し，翼性能との関係について考察を行った。

\section{2. 实験手法}

\section{$2 \cdot 1$ 实検装昌}

図 1 に使用した実験装置を示す，装置はエッフェル型の低速風洞で，遠心圧縮式のブロアから吸い込まれた作 動流体は風洞部を通過し, 下流の直線翼列に流入する構造となっている.直線翼列は 7 枚の翼で構成されており, 翼端において翼支持プレートで支持された各翼は，翼列側板に設けられたスリットを通して交換する事が可能と なっている. 本研究では, 航空機用高負荷低圧タービン翼である Type A 翼と, Type A 翼の後椂厚みを削減した Type B 翼の 2 種類に関して調查を行った。 Type A 翼の仕様としては, コード長 $\mathrm{C}=114[\mathrm{~mm}]$, 軸コード長 $\mathrm{Cx}=100$ $[\mathrm{mm}]$, 翼ピッチ $\mathrm{t}=89[\mathrm{~mm}]$, スパン長さ $260[\mathrm{~mm}]$, 設計流入角 45.6 [deg], 設計流出角-62.4 [deg]である.

図 2 には直線翼列装置に設けられた後流発生装置（Wake Generator）を示す. Wake Generator は 2 本のタイミン グベルト間に 68 本の円柱を取り付け, ベルトをモーターで駆動する事により, 上流静翼列から生ずる wake を相 対的に模擬している. 使用円柱はステンレス製で，直径は $3 \mathrm{~mm}$, 円柱ピッチは $63.5 \mathrm{~mm}$ である. 円柱移動速度は 光電回転検出計を用いて算出し, 試験条件に合わせて調整を行っている. なお, wake 非流入条件時には円柱を取 り外し，影響がないようにしている.

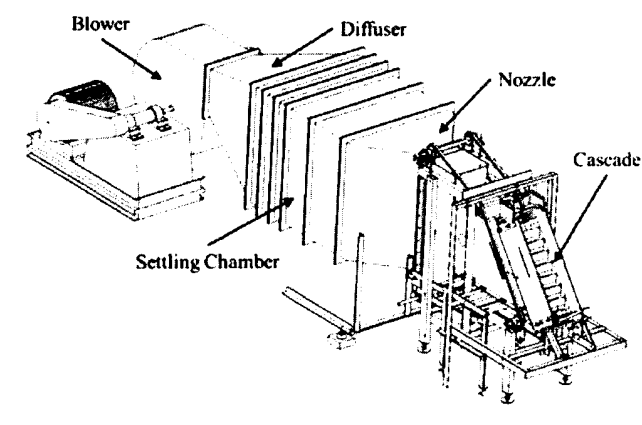

Fig. 1 Experimental Facility

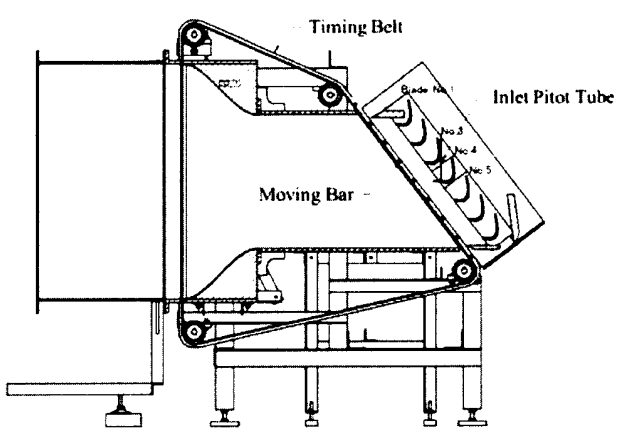

Fig. 2 Detail of Wake Generator

\section{$2 \cdot 2$ 汁測手法}

本研究ではミニチュアピトー管を用いた空力計測と，熱線流速計を用いた翼負圧面境界層及び翼下流流れ場の 計測を実施した．図 4 に空力計测時の計測幾何を示す．空力計測では，翼列中心翼のミッドスパン前縁を基点と して，30\% Cx 上流地点での圧力を翼列入口圧力情報， $115 \% \mathrm{Cx}$ 下流ラインにおいてピトー管をピッチ方向にトラ バースして取得したものを翼列出口圧力情報として使用し，翼列損失を算出している.

図 4 には，境界層計測及び翼下流流れ場計測での計測格子を示す．計測には，KANOMAX 社製定温度型熱線 流速計システム MODEL1011 と DANTEC 社製 I 型熱線プローブ 55P11 を使用した．両計測共に，中心翼ミッド スパン上で計測を行っている，境界層計測では，翼前縁より $60 \% \mathrm{Cx}$ 下流から $98 \% \mathrm{Cx}$ 下流までの翼負圧面上を， 翼面法線方向 0.2 10mm の領域でトラバースして計測を行った. 翼下流流れ場計測では, 翼後縁を原点, 設計流 出角方向を軸として，4\%Cx 下流から $80 \% \mathrm{Cx}$ 下流までを，正負圧面側それぞれ $15 \% \mathrm{Cx}$ までの範囲で，設計流出 角法線方向にトラバースして計測を行った. 


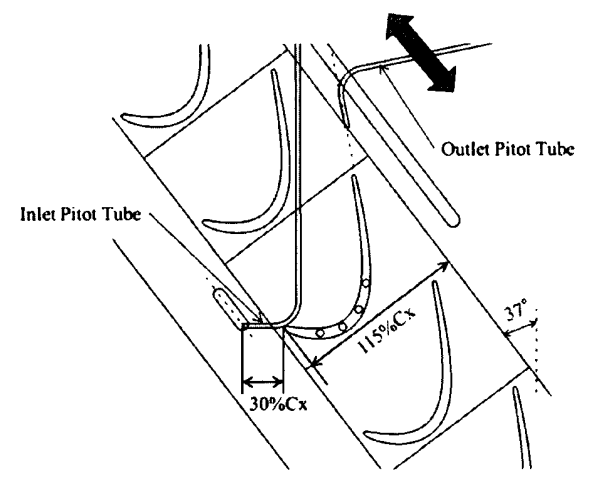

Fig. 3 Aero Measurement Geometry

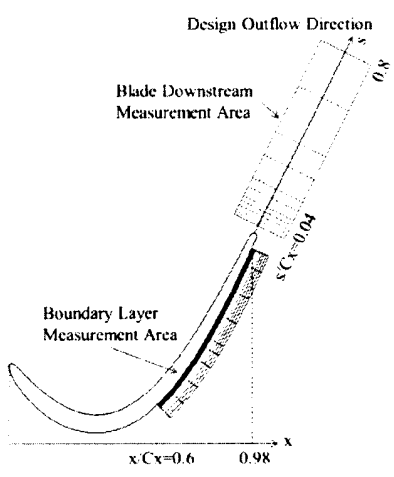

Fig. 4 Measurement Grid for Single Hot Wire

\section{$2 \cdot 3$ 試㰸堡件}

試験条件には, 式 (1)，式（2）で定義されるレイノルズ数とストローハル数を与えている.レイノルズ数は, コード長と翼列出口での翼 1 ピッチ平均流速で定義し $40,000 ， 57,000 ， 100,000 ， 170,000$ の 4 条件で実施した. 本研究においては, $\mathrm{Re}=40,000$ と 57,000 は高高度での低レイノルズ数条件, $\mathrm{Re}=100,000$ と 170,000 は離着陸時の 高レイノルズ数条件を想定している. ストローハル数は円柱通過周波数, コード長, 翼列入口平均流速で定義し, Wake Generator を使用しない wake 非流入条件 $(\mathrm{St}=0.0)$ と, 作動させた wake 流入条件 $(\mathrm{St}=0.8)$ 0) 2 条件で実施 した.

$$
\begin{aligned}
& \operatorname{Re}=\frac{C \overline{V_{2}}}{v} \\
& S t=\frac{f_{b p} C}{V_{1}}
\end{aligned}
$$

\section{3. 結果と考察}

\section{$3 \cdot 1$ wake 非流入条件における後緑形状の効果}

図 5 , 図 6 に, 空力計測で得られた全圧損失係数分布及び，流量平均翼列損失を示す．なお，全圧損失係数は Type A 翼 Re=100,000 での損失ピーク值で, 流量平均翼列損失は Type A 翼 Re $=100,000$ での值でそれぞれ標準化し ている. まず，レイノルズ数別に比較を行うと，全圧損失係数分布より，両翼条件共にレイノルズ数が低くなる につれ，特に負圧面での損失が増大している. 流量平均翼列損失からもレイノルズ数低下に伴う損失増大の傾向 が確認できる. 次に，翼型別の比較を行うと，全圧損失倸数分布より， Re=40,000 の条件では負圧面側において Type B 翼での損失が増大している. 一方で, $\mathrm{Re}=100,000$ の条件では損失のピークに大きな差異が見られ, Type B 翼での損失ピーク值が軽減される傾向を確認できる. 流量平均翼列損失からも $\mathrm{Re}=100,000$ 以上の高レイノルズ 数条件では Type B 翼の損失が改善されている傾向が確認できる.

図 7 には, $R e=40,000$ と 100,000 の条件において, 境界層計測及び翼下流流れ場計測で取得した時間平均速度プ ロファイルを示す．まずは，レイノルズ数別に比較を行う. 境界層計測の結果より, $\mathrm{Re}=40,000$ の条件において は,いずれの翼条件においても翼面境界層が高さ方向に大きく発達しており,巨大な剥離泡の存在が破認できる. この剥離泡は翼後縁付近に至っても存在したままで, 翼面上での流れ場は burst 流れとなっている. 一方の $\mathrm{Re}=100,000$ では, 流れ場は一旦剥離するものの, $\mathrm{x} / \mathrm{Cx}=0.9 \sim 0.95$ 付近に执て遷移し, 翼面に再付着している. 翼下流流れ場計測からは, wakeの挙動が確認出来る. $\mathrm{Re}=40,000$ の結果では, 翼面上での大規模な剥離泡の影響 により大きな wake 幅が確認できる. 次に, 翼型別の比較を行う. $\mathrm{Re}=40,000$ の条件においては, Type B 翼の低 速領域 (剥離, 境界層) が Type A 翼よりも高さ方向に扡大している.この傾向は翼下流の wakeにも表れており, Type B 翼の wake 幅が増大している. Re $=100,000$ の条件では, $\mathrm{x} / \mathrm{Cx}=0.98$ において Type B 翼の翼面近傍での流速 
は減少し，境界層高さについては縮小する傾向を得ている．翼下流の wake に関しては，翼後縁直後の wake 幅が 細くなり， s/Cx=0.1 以降においては Type B 翼での速度欠損のピークが抑えられている.

図 9 に, 翼下流流れ場計測で取得した wakeの運動量厚さを示す. 運動量厚さは各計測地点での設計流出角法 線方向で最も低速な地点を wake 中心として，そこから正圧面側と負圧面側に分割し，それぞれの側で局所最大 流速の 98\%の流速を持つ地点までを積分範囲として算出している. 結果を見ていくと，低レイノルズ数条件にお いて Type B 翼の運動量厚さが全体的に高く, また $\mathrm{s} / \mathrm{Cx}=0.1$ 付近で流れ方向に対する変化量が急峻となっている. 一方, 高レイノルズ数条件では, 全体的に Type B 翼の運動量厚さが低い值となっており，これらの結果は図 6 に示した流量平均翼列損失の大小関係の傾向と一致している.

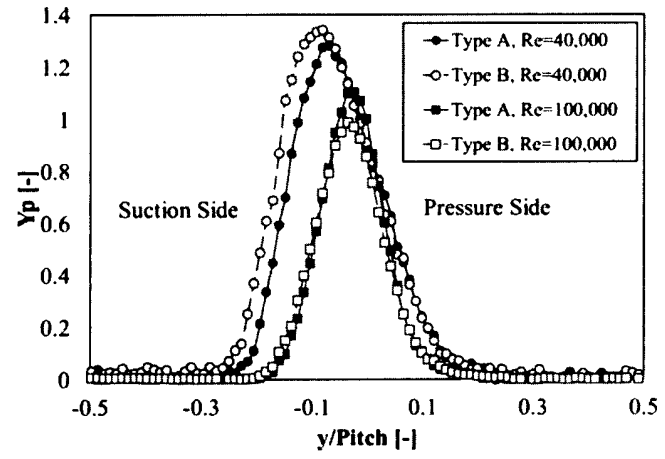

Fig. 5 Yp Distributions (St $=0.0)$

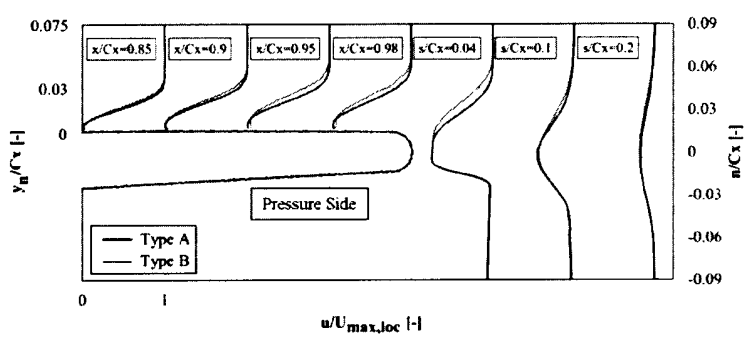

Fig. 7 Time Averaged Velocity Profile $(\mathrm{Re}=40,000, \mathrm{St}=0.0)$

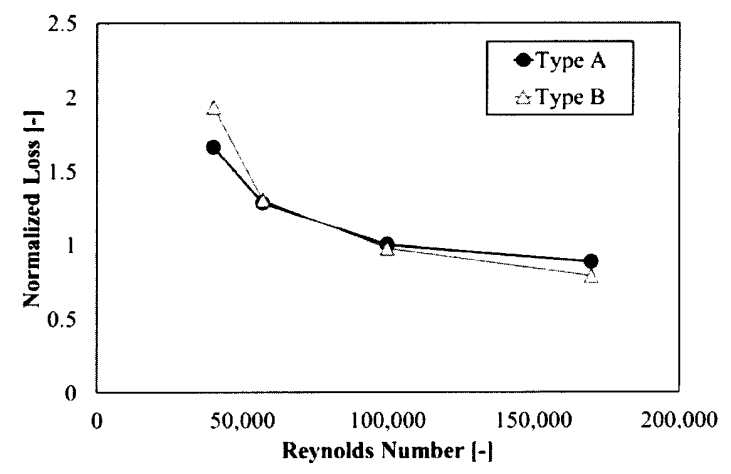

Fig. 6 Mass Averaged Cascade Loss ( $\mathrm{St}=0.0)$

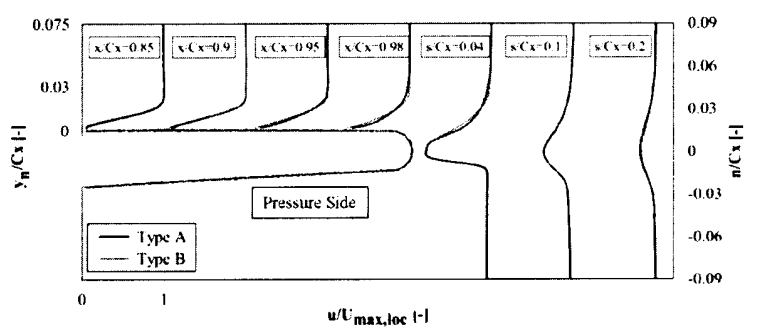

Fig. 8 Time Averaged Velocity Profile $(\mathrm{Re}=100,000, \mathrm{St}=0.0)$

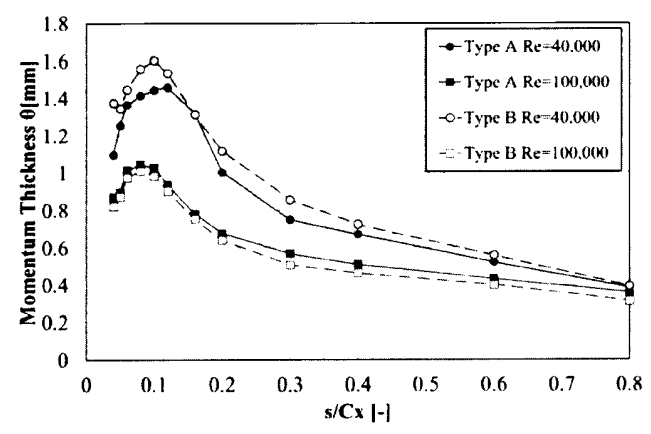

Fig. 9 Time-Averaged Momentum Thickness at Downstream of Blade

\section{$3 \cdot 2$ wake 流入条件における後縜形状の効果}

図 10, 図 11, 図 12 に, wake を流入させた条件での全圧損失係数分布及び流量平均翼列損失を示す. それぞれ の結果は wake 非流入条件と同様に, Base TE 翼 $\mathrm{Re}=100,000$ での值で無次元化している. $R e=40,000$ の条件では, wake 非流入条件で Type B 翼の負圧面において顕著に表れていた損失が見られなくなっている.これは，翼負圧 面において存在していた大規模な剥離泡が，wake の流入によって時間平均的に抑制された事によるものである. 一方の $\mathrm{Re}=100,000$ においては, wake 非流入条件と同様に Type B 翼の損失ピーク值が軽減されている.これらの 
傾向は流量平均翼列損失の結果からも確認でき, Type B 翼の翼列性能は, $R e=40,000$ の条件では Type $\mathrm{A}$ 翼と同等, $\mathrm{Re}=57,000$ 以上の条件では Type A 翼よりも改善される結果が得られた.

また，図 13 には $\mathrm{Re}=40,000$ の wake 流入条件における, 翼下流 wake の運動量厚さを示している. Type A 翼と Type B 翼の運動量厚さは全体的に同等の值を示しており,この事からも wake が流入することによって Type B 翼の低レイノルズ数条件での翼列性能の覀化が改善されている傾向が確認できた.

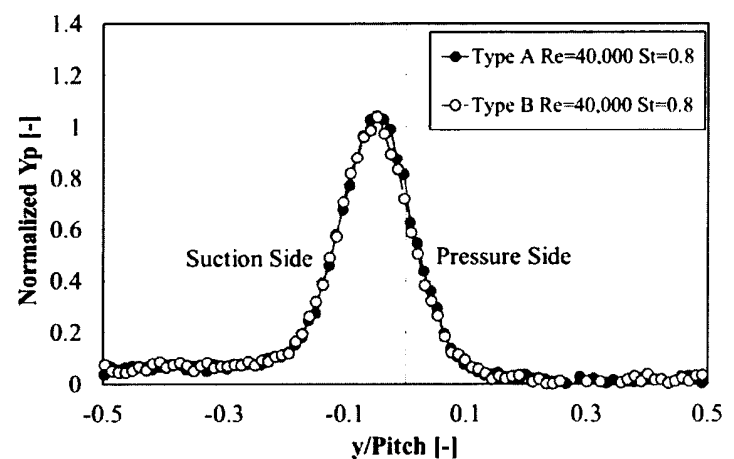

Fig. 10 Yp Distributions at $\mathrm{Re}=40,000(\mathrm{St}=0.8)$

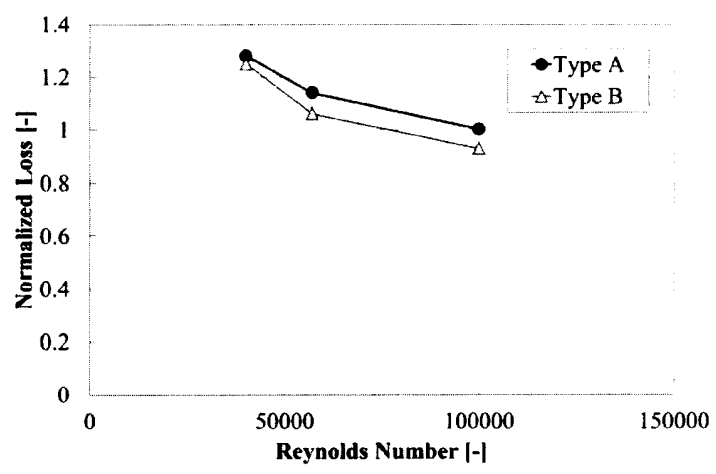

Fig. 12 Mass Averaged Cascade Loss ( $\mathrm{St}=0.8)$

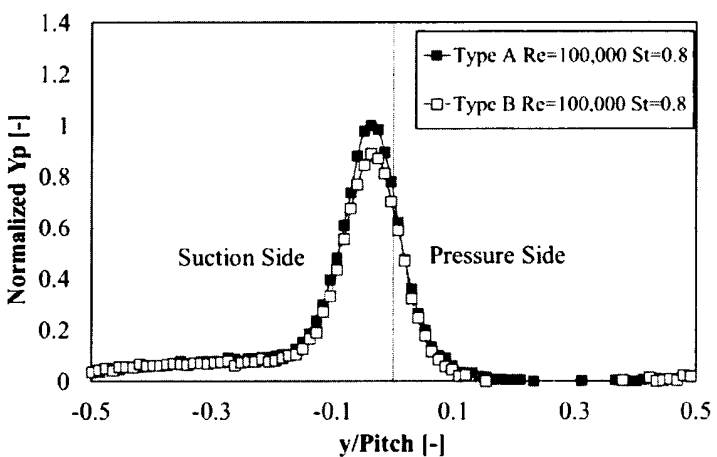

Fig. 11 Yp Distributions at $\mathrm{Re}=100,000(\mathrm{St}=0.8)$

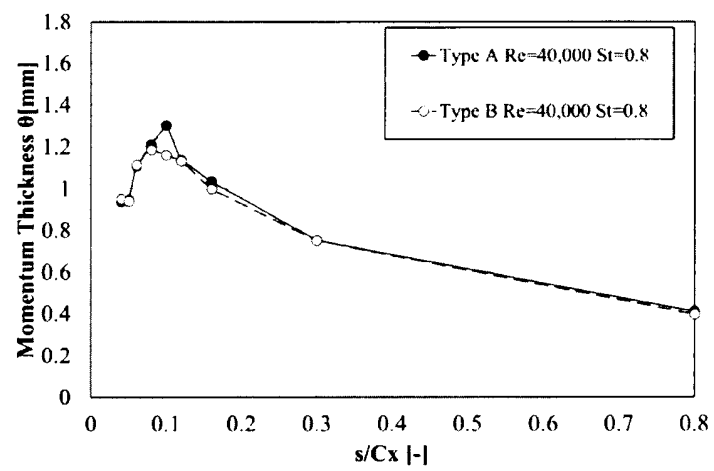

Fig. 13 Time-Averaged Momentum Thickness at Downstream of Blade $(\mathrm{St}=0.8)$

\section{4. 結}

本研究では, 航空エンジン用高負荷低圧タービン翼の後縁厚みを削減したタービン翼モデルに関して調査 を行い，翼性能に与える効果に関して以下の知見を得た。

・低レイノルズ数条件において, 翼面上での流れがバーストする流れ場では, 剥離や翼面境界層が高さ方 向に更に成長し，翼性能は悪化する.

・ 高レイノルズ数条件では, 後縁付近の翼面近傍での流速は低下し, 境界層厚さは減少する. 翼後縁直後 では wake 幅は細くなり，それ以降では速度欠損のピークが抑えられ，翼性能は改善している.

・ wake を流入させた条件では，翼面での剥離が時間平均的に抑制され，低レイノルズ数条件における翼 性能の亜化が改善される. 高レイノルズ数条件における翼性能の改善は wake 流入条件でも確認できる.

\section{文献}

(1) Schulte, V., Hodson, H.P., "Prediction of the Becalmed Region for LP Turbine Profile Design", Journal of Turbomachinary, Vol. 1.120, (1998), pp. 839-846. 